This item was submitted to Loughborough's Research Repository by the author.

Items in Figshare are protected by copyright, with all rights reserved, unless otherwise indicated.

\title{
Caffeine improves performance but not duration of the countermovement jump phases
}

\section{PLEASE CITE THE PUBLISHED VERSION}

https://doi.org/10.23736/S0022-4707.20.11099-5

PUBLISHER

Edizioni Minerva Medica

VERSION

AM (Accepted Manuscript)

\section{PUBLISHER STATEMENT}

This paper was accepted for publication in the journal The Journal of Sports Medicine and Physical Fitness and the definitive published version is available at https://doi.org/10.23736/S0022-4707.20.11099-5

LICENCE

CC BY-NC-ND 4.0

\section{REPOSITORY RECORD}

Lago-Rodríguez, Ángel, Pablo Jodra, Stephen Bailey, and Raúl Domínguez. 2020. "Caffeine Improves Performance but Not Duration of the Countermovement Jump Phases”. Loughborough University. https://hdl.handle.net/2134/13280327.v1. 
Caffeine improves performance but not duration of the countermovement jump phases Ángel LAGO-RODRÍGUEZ ${ }^{1}$, Pablo JODRA ${ }^{2}$, Stephen BAILEY $^{3}$, Raúl DOMÍNGUEZ ${ }^{1}$

${ }^{1}$ Faculty of Health Sciences, University Isabel I. Burgos. Spain; ${ }^{2}$ Faculty of Education, University of Alcalá. Madrid. Spain; ${ }^{3}$ School of Sport, Exercise and Health Sciences, Loughborough University. Loughborough. United Kingdom

*Corresponding author: Pablo Jodra. Faculty of Education, University of Alcalá. Madrid, Spain. E-mail: pablo.jodraj@uah.es

\section{ABSTRACT}

BACKGROUND: The countermovement jump (CNN) test is often employed to assess power generated in the lower limbs and has been related fo performance in several sports modalities. The objective of this study was to assess the effects of caffeine supplementation on jump height, average power (AD), peak power (PP), maximum velocity $\left(\mathrm{V}_{\text {max }}\right)$, force production and duration of the ecentrie, isometric and concentric muscle contraction phases of a CMI.

METHODS: Sixteen resistance-trained men Gage: $22.69 \pm 2.12$ years; height: $1.78 \pm$ $0.06 \mathrm{~m}$; weight: $78.09 \pm 10.27 \mathrm{~g}$ ) perfommed a CMJ 60 minutes after having taken an oral suppiement containing 6 mg $\cdot \mathrm{kg}^{-1}$ of caffeine or placebo (sucrose). The study design was randornized, double-bind crossover.

RESULTS: Carieine ingestion improved jump height $(+3.86 \%, \mathrm{p}=0.02), \mathrm{V}_{\max }(+1.49 \%$, $\mathrm{p}=0.923), \mathrm{AP}(+4.83 \%, \mathrm{p}=0.006)$, and PP $(+3.49 \%, \mathrm{p}=0.004)$.

CONCLUSIONS: Acute caffeine supplementation leads to improved CMJ height, $\mathrm{V}_{\max }$, AP and PP without significantly affecting the duration of the different test phases. Therefore, caffeine supplementation may be employed as ergogenic aid in sports where CMJ performance has been associated with sport-specific performance enhancements.

Key words: muscle strength; coffee; sports performance; ergogenic substances. 


\section{TEXT}

\section{Introduction}

Vertical jump tests are often used to assess physical fitness in both athletes and untrained individuals ${ }^{1}$. The countermovement jump (CMJ) is one of the tasks used to measure vertical jump performance ${ }^{2}$. Phosphocreatine degradation is the main energy system involved in $\mathrm{CMJ}$ performance ${ }^{3}$, since maximum exertion is needed for a short duration ( 2 seconds). At the neuromuscular level, CMJ execution requires brief contraction times and high rates of force development ${ }^{4}$. Therefore, $\mathrm{CMJ}_{\mathrm{J}}$ perfornance is determined by the contractile and neuromuscular control properties of the entire musculoskeletal system ${ }^{5}$, and jump height, power and force production during CMJ execution are indicators of lower limb muscular power Farthermore, CMJ performance has been associated with speed andacceleration sprinting $^{2}$ and also with success in team sports like basketball and volleyball ${ }^{7}$, or soccer ${ }^{8}$.

Because of similar competitive levels between elite athletes of any given sport, a modest performance improvement can be sufficient to make a difference to performance outcome. To pursue such irnprovements, athetes take sport supplements like caffeine, which has been detected in sport competitions in three out of every four elite athletes ${ }^{8}$. In the 1970s, the ergogenicity docaffeine was believed to be related to enhanced lipolysis and enhanced muscle glyogen spare. Currently, however, the ergogenic effects of carfeine supplementation are attributed to the antagonistic effects of caffeine gn adenosine receptors 9 . Caffeine binding to adenosine receptors is thought to delay fatigue through a mechanism whereby the inhibitory actions of adenosine on the release of excitatory neurotransmitters are offset, which results in enhanced neuronal excitability ${ }^{10}$, leading to improved endurance performance along with a reduction in the rate ratings of perceived exertion $(\mathrm{RPE})^{9}$. In addition to its effects on the nervous system, caffeine also induces changes at the metabolic level-, increasing blood norepinephrine concentrations and glycolytic activity_, as well as at the neuromuscular level—, increasing the recruitment of motor units and muscle contractile force- ${ }^{11}$.

Altogether, these effects contribute to enhanced CMJ performance after caffeine supplementation. Improved CMJ performance after caffeine intake has been observed in athletes competing in various sports such as volleyball ${ }^{12,13}$, Brazilian Jiu-Jitsu ${ }^{14}$, 
swimming $^{15}$, badminton ${ }^{16}$, soccer $^{8,17}$, and basketball ${ }^{18}$, as well as recreational athletes ${ }^{19}$. Several of these studies assessed the effects of caffeine supplementation on CMJ jump height and power. However, few studies have examined the potential ergogenic effect of caffeine ingestion on jump velocity and force ${ }^{13,14,19}$. Moreover, it is not yet known whether caffeine supplementation alters the duration of the different $\mathrm{CMJ}$ jump phases (i.e., eccentric, isometric, concentric). Given that caffeine modifies muscle contraction properties $^{11}$, and that jump duration has been associated with changes in muscular contractility $^{7}$, the aim of this study was threefold: i) to examine whether caffeine ingestion affects the duration of the eccentric, isometric and concentric CMJ phases; ii) to assess its effects on jump velocity and force; and iii) to eonfirm evaluate its reported ergogenic effect on CMJ height and power.

\section{Materials and methods}

\section{Participants}

Sixteen healthy men with experjence in resistance trai⿱丆贝乛亅ing (age $22.69 \pm 2.12$ years; height: $1.78 \pm 0.06 \mathrm{~m}$; weight: $78.09 \pm 10.27 \mathrm{~kg}$; BMI: $20152 \pm 2.74 \mathrm{~kg} / \mathrm{m}^{2}$ ) participated in this study. Inclusion criteria were: a) experience in resistance training (at least 18 months of three weekly sessions); b) a one-repetifion maximum (1 RM) higher than body mass in the bench press and of 1.5 of ody mass in squat exercise; c) no sports supplement taken in the previgus three months; d) no smoking; e) no cardiovascular, pulmonary or neurological disease; and f) to not be considered an elite athlete. In a preliminary session, two researchers informed candidates about the procedure and the dietary requirements or participating in the study. All participants signed an informed consent formi. The study protocol was approved by a local Ethics Committee (Chairperson: Dr. Francisco Javier Martín del Burgo; Protocol number: UI1-PI002; Date of approval: 12/11/2019).

\section{Experimental design}

The study design was randomized, double-blind crossover. After the initial informative session, each participant completed two sessions within the same time frame $( \pm 0.5$ hours) at the Exercise Physiology laboratory. In each session, participants ingested caffeine (CAFF) or placebo (PLAC) 60 min before the start of a standardized warm-up. After the warm-up, subjects performed a CMJ test. 


\section{Supplementation and diet control}

Subjects arrived at the laboratory $75 \mathrm{~min}$ before the session onset, when they were given a red capsule (Guinama S.L.U, 0044634, La Pobla de Valbona, Spain) containing CAFF (6 $\left.\mathrm{mg} \cdot \mathrm{kg}^{-1}\right)$ or PLAC (6 $\mathrm{mg} \cdot \mathrm{kg}^{-1}$ of sucrose). Supplement timing was based on knowledge that caffeine reaches peak concentrations in blood 1 hour after its intake, and on its established degradation time of 13.4 minutes $^{20}$.

To avoid the effect of varied nutritional intake impacting our outcome measures, participants were issued dietary guidelines targeting the intake of $60 \%$ carbohydrates, $30 \%$ lipids and $10 \%$ proteins. Subjects were also instructed to avoid foogs rich in caffeine (coffee, tea, chocolate, mate, energy drinks, cola drinks and choc@iate drinks).

\section{Capacity of the lower limbs to generate elastic-explosive force}

Subjects performed a warm-up consisting of 5 min of pedaling at a self-selected submaximal workload on a cycle ergometer. After 1 min of passive rest, a specific warm up was started which consisted of 3 min of cycle exereise at $120 \mathrm{~W}(60 \mathrm{rpm})$ and a maximum $5 \mathrm{~s}$ sprint completed at the end of each minute. After $2 \mathrm{~min}$ of rest, subjects performed five CMJs of increasing intensity on a farce platform (Quattro Jump model 9290AD; Kistler Instruments. Winterthur, Switseriand) with 45 s of rest between jumps.

Mean values from two jumps were recorded for the following variables, which have been reiated to the capacity of the legs to generate elastic-explosive force ${ }^{21}$ : jump height $(\mathrm{H})$, eceentric phase duration $\left(\mathrm{T} \_\right.$Ecc), isometric phase duration $\left(\mathrm{T}_{-} \mathrm{Iso}\right)$, concentric phase duration (T_Cond, Rea power (PP), average power (AP), peak velocity $\left(\mathrm{V}_{\max }\right)$, initial force $(I F)$ and peak force $\left(F_{\max }\right)$.

\section{Statistical analysis}

The normality of data was first checked using the Kolmogorov-Smirnov test. To assess the effects of supplementation (PLAC and CAFF) on the different performance variables recorded during the CMJ test, paired samples t-tests were performed. For non normally distributed variables, a Wilcoxon signed-rank test was used. Effect sizes (d) were calculated using Cohen's $d$, and interpreted as: large ( $d>0.8)$, moderate $(d=0.8$ to $0.5)$, small $(\mathrm{d}=0.5$ to 0.2$)$, and trivial $(\mathrm{d}<0.2)$. All statistical tests were performed using 
the Statistical Package for Social Sciences (version 20.0 for Mac, SPSS ${ }^{\mathrm{TM}}$ Inc, Chicago, IL, USA). Statistical significance was set at $p<0.05$.

\section{Results}

\section{\#\#\# Table 1 near here \#\#\#}

The results of CMJ jump capacity according to treatment (PLAC vs. CAFF) are provided in Table 1 . The paired t-test revealed significant differences between the conditions PLAC and CAFF in the variables: $\mathrm{H}$ (Fig. $1 \mathrm{~A} ; 32.1 \pm 4.71$ vs. $33.34 \pm 4.44$ $\left.\mathrm{cm} ; \mathrm{t}_{15}=-2.609 ; \mathrm{p}=0.02 ; \mathrm{d}_{\mathrm{z}}=0.65\right), \mathrm{V}_{\max }\left(\right.$ Fig. $1 \mathrm{~B} ; 2.68 \pm 0.16 \mathrm{v} \Omega 2.72 \pm 0.17 \mathrm{~m} / \mathrm{s} ; \mathrm{t}_{15}$ $\left.=-2.522 ; \mathrm{p}=0.023 ; \mathrm{d}_{\mathrm{z}}=0.63\right)$, PP (Fig. $1 \mathrm{C} ; 51.54 \pm 4.62$ vs $53.34 \pm 6 \mathrm{~N} / \mathrm{k} ; \mathrm{k} 15=-$ 3.427; $\mathrm{p}=0.004 ; \mathrm{d}_{\mathrm{z}}=0.86$ ), and AP (Fig. 1D; $28.59 \pm 3.45$ vs. $29.97 \pm 3.67$ d $8 / \mathrm{kg} ; \mathrm{t}_{15}=$ -3.235; $\left.\mathrm{p}=0.006 ; \mathrm{d}_{\mathrm{z}}=0.81\right)$. No significant differences were detected for ine remaining variables ( $p$ > 0.05; see Table 1 for details).

\#\#\# Figure 1 near here \#\#\#

\section{Discussion}

The aim of this work was threefold: i) to test whether eafteine ingestion leads to changes in the duration of the eccentric, isometric and eorcentric phases of a $\mathrm{CMJ}$; ii) to atse assess the effects of caffeine supplementation on jump velocity and force; and iii) to eonfirm evaluate prior findings of anergogeniceffect of caffeine on CMJ height and power. We observed that caffeinessupplementation significantly enhanced $\mathrm{H}, \mathrm{PP}, \mathrm{AP}$, and $\mathrm{V}_{\mathrm{max}}$. Moreover, CAFF showed potential ergogenic effect on IF and $\mathrm{F}_{\max }$. However, we failed to find an effect of caffeine supplementation on duration of the eccentric, isometric, and concentric $\mathrm{CMJ}$ phases.

The improvement observed in CMJ jump height after caffeine supplementation $(+3.86 \%, \mathrm{p}=0.02)$ in resistance-trained subjects confirms evidence previously observed in jump duration in elite volleyball players $(+5.3 \%)^{13}$, and in jump height in competitive volleyball players $(+3.4 \%)^{12}$, elite Brazilian Jiu-Jitsu athletes $(+3.7 \%)^{14}$, elite badminton players $(+5.0 \%)^{16}$, national standard swimmers $(+3.0 \%)^{15}$ and national level basketball players $(+2.1 \%)^{18}$. In contrast, other investigations examining the effects of combined caffeine and carbohydrates supplementation failed to detect improvements in vertical jump height in volleyball players ${ }^{3}$ or in CMJ height in amateur football players ${ }^{17}$. A common feature of both these investigations is that, while the effects of caffeine supplementation on jump height were assessed in a vertical jump test, measurements 
were made after an exercise session. Given that the CMJ requires maximal neuromuscular effort ${ }^{5}$, it is likely that the fatigue produced by exercise impaired optimal jump performance and this could compromise the ergogenic effect of caffeine. Moreover, Pfeifer et al. ${ }^{3}$ administered $100 \mathrm{mg}\left(\sim 1.34 \mathrm{mg} \cdot \mathrm{kg}^{-1}\right)$ of caffeine as a gel, which is provided a dose much lower than administered in our study $\left(6 \mathrm{mg} \cdot \mathrm{kg}^{-1}\right)$ and in studies reporting an ergogenic effect ${ }^{13,14,16}$, when the administered dose was $3-6 \mathrm{mg} \cdot \mathrm{kg}^{-1}$ which has been reported to increased leg muscle strength ${ }^{22}$.

The height reached in a CMJ is determined by the $\mathrm{V}_{\max }$ recorded guring the jump, such that jump height can be calculated from $\mathrm{V}_{\max }$ which, in turn, corresponds to the vetocity recorded at takeoff ${ }^{23,24}$. This would explain the greater $V_{\max }$ cosserved in our study following CAFF supplementation compared to PLAC $(+1.40 \%, \mathrm{p}=0.023)$ and is consistent with previous studies, which reported greater $V_{\max }$ (Jacốson, 2018) along with a longer jump duration ${ }^{13}$ and height ${ }^{14}$ after cafteine supplemientation.

We observed that improvements in CMJ height coincided withigher levels of both AP $(+4.83 \%, \mathrm{p}=0.006)$ and PP $(+3.49 \%, \mathrm{p}=0.004)$, confirming previsus reports of higher PP values $(+1.2-16.2 \%)^{8,12,13}$ following caffeine supplementation. Jacobson et al. ${ }^{19}$ noted a $2.3 \%$ improvement in PP following acate cafferine supplementation, though the difference did not attain statistical significanee. However, the timing of supplementation used by Jacobson et al. ${ }^{19}$ differed from the timing used both in our study and the remaining studies that have detected inceased PP after caffeine intake s.13,18. $^{8}$. Specifically, Jacobson et al. 19 administered eaffeine $30 \mathrm{~min}$ before exercise, whereas caffeine was ingested 69 min before the performance test in studies reporting an ergogenic effect of eaffeine supplementation. Given that peak blood caffeine concentrations is attained 45-60 min post caffeine ingestion, it is likely that the test in the study by Jacobson et al. ${ }^{19}$ was executed before peak caffeine concentrations were reached, thereby compromising the ergogenic potential of caffeine. Our results, in combination with those available in the literature, lend support to the notion that CMJ height is associated with the power levels exerted during the jump ${ }^{23,24}$.

As for the force recorded during the concentric phase of the CMJ, Zbiden-Foncea et al. ${ }^{13}$ observed greater strength $\left(F_{\max }\right)$ after caffeine consumption, while we noted no significant differences between PLAC and CAFF; although we did detect a trend towards significance both for $\mathrm{F}_{\max }(\mathrm{p}=0.053)$ and $\mathrm{IF}(\mathrm{p}=0.06)$. Our findings are therefore in line with the hypothesis that peak force may not be the best measure of vertical jump 
performance ${ }^{25}$ unlike other variables such as $\mathrm{V}_{\max }$, AP and $\mathrm{PP}$, which improved concurrently with jump height following caffeine supplementation. Jump duration has been associated with muscular contractility ${ }^{7}$, which may be modified through caffeine supplementation ${ }^{11}$. Our findings, nevertheless, suggest that caffeine does not affect the duration of the different jump phases (T_ecc, T_iso and $T_{-}$con), despite our observed improvements in jump height, $\mathrm{V}_{\max }$, AP and PP following caffeine supplementation. These disparate results may be explained by the low correlation reported for CMJ duration and height ${ }^{24}$, and there is evidence to suggest that T_ecc and T_con are poor indicators of the height reached in a CMJ ${ }^{23}$. Similarly, when Thoriund ${ }^{26}$ compared CMJ performance before and after a handball match, it was observed that fatigue led to a decrease in both jump height $(5.2 \%)$ and $V_{\max }$, wition no changes produced in $\mathrm{T}_{\mathrm{E} \mathrm{Ecc}}$ and $\mathrm{T}$ _Con ${ }^{26}$. Finally, in an investigation conducted by García-Pinillos et al. ${ }^{27}$, increased jump capacity was observed in some runnars following a racing session (post-activation potentiation, PAP), withøut differegres in jump duration. Therefore, based on our findings and those reported in the aforementioned studies, it seems reasonable to suggest that the duration of the differenniump phases may not be good indicators of the potential ergogenic effect of eaffeine on the execution of a CMJ. However, if we consider that for a given 1 con value, $V_{\max }$ was greater during the concentric CMJ phase after the intake or caffeine, we may infer that CMJ movement during the concentric phase was greater fol authors have observed that, as opposed the duration of the different jump phases, the knee fiexion angle influences CMJ performance, increasing jump height as the consequence of an inereased movement range ${ }^{28}$. Hence, it could be that caffeine supplementation vereases the velocity of movement via improved intramuscular coordination along with increased neuromuscular recruitment ${ }^{10}$ leading to a greater range of knee flexion and $\mathrm{V}_{\max }$ in the $\mathrm{CMJ}$ in response to caffeine intake. As a future line of research, we propose examining the effect of acute caffeine supplementation on the degree of knee flexion during the CMJ.

Caffeine acts antagonistically on adenosine receptors and offsets the negative effects of adenosine on neural drive, neuromuscular recruitment is increased ${ }^{10}$. Caffeine has been attributed a positive effect on intra- and inter-muscular coordination during muscle contractions ${ }^{29}$. Hence, part of the caffeine effect can be explained by increased motor unit recruitment ${ }^{30}$ and an increase in neuromuscular efficiency ${ }^{31}$, thus resulting in 
greater power output. Therefore, improved CMJ performance in the current study following caffeine ingestion is likely a result of enhanced neuromuscular function.

\section{Conclusions}

Acute supplementation with $6 \mathrm{mg} \cdot \mathrm{kg}^{-1}$ of caffeine improved CMJ performance $60 \mathrm{~min}$ post ingestion. Our data indicate that improved jump height after caffeine intake was paralleled by improvements also in $\mathrm{V}_{\max }$, AP and PP with no effects on the duration of the different muscle contraction phases of the jump (eccentric, isometric, concentric). In contrast, we observed no improvements in force following caffeine supplementation, supporting the notion of Kirby et al. ${ }^{25}$ that the force generated in a CMJ is not the best predictor of jump height.

\section{Practical applications}

- Caffeine supplementation may be usedas ergogeniogaid in sports where the ability to accelerate and sprint is crucial for performance.

- Caffeine supplementation may improve performanee in team-sports involving jump actions (i.e., soecer, basketball, vôteyball,

- Due to its ergogenic effects on jump height but not on the different jump duration phases, caffeine supplementation may be used in sport modalities where athletes seek to achieve a maximum vertical displacement of the center of mass through jumging with no timing restrictions (i.e., high jump in athletics), either during competition or training sessions. 


\section{REFERENCES}

1. Balsalobre-Fernández C, Glaister M, Lockey RA. The validity and reliability of an iPhone app for measuring vertical jump performance. J Sport Sci 2015; 33(15):1574-1579.

2. Stanton R, Wintour SA, Kean CO. Validity and intra-rater reliability of MyJump app on iPhone 6s in jump performance. J Sci Med Sport 2017; 20(5):518-523.

3. Pfeiffer DR, Arvin KM, Herschberger CN, Haynes NJ, Renffow MS. ARdow Dose Caffeine and Carbohydrate Supplement does not Improve Athletic Performance during Volleyball Competition. Int Exerc Sci 2017); 10(3):340353. https://www.ncbi.nlm.nih.gov/prne/articles/PMC5421074/

4. Sabol F, Grgic J, Mikulic P. The effects of 3 different doses deaffeine on jumping and throwing performance: A randonizes, doublesolind, crossover study. Int J Sport Physior 2019; 14(9):11709177/,

5. Bobbert MF, Van Soest A.'. Why do people jogres the way they do? Exerc Sport Sci Rev 2091; 29(3):95-102.

6. Markovic G, Dizdar D, Jukic I, Gardinate M. Reliability and factorial validity of squat and countermorement jump tests. J Strength Cond Res 2004; 18(3):551555.

7. Rodacki ALF, Fowler NE, Bennett SJ. Multi-segment coordination: Fatigue effects. Med Sci Sport Exer 2001; 33(7):1157-1167.

8. Lara B, Gonzalez-Millán C, Salinero JJ, Abian-Vicen J, Areces F, BarberoAlvarez JC, et al. Caffeine-containing energy drink improves physical performance in female soccer players. Amino Acids 2014; 46(5):1385-1392.

9. Doherty M, Smith PM. Effects of caffeine ingestion on rating of perceived exertion during and after exercise: A meta-analysis. Scand J Med Sci Spor 2005; 15(2):69-78. 
10. Davis JM, Zhao Z, Stock HS, Mehl KA, Buggy J, Hand GA. Central nervous system effects of caffeine and adenosine on fatigue. Am J Physiol-Reg I 2003; 284(2):R399-R404.

11. López-González LM, Sánchez-Oliver AJ, Mata F, Jodra P, Antonio J, Domínguez R. Acute caffeine supplementation in combat sports: A systematic review. J Int Soc Sport Nutr 2018; 15(1):60-70.

12. Pérez-López A, Salinero JJ, Abian-Vicen J, Valades D, Lara B, Hernández C et al. Caffeinated energy drinks improve volleyball performance in elite female players. Med Sci Sport Exer 2015; 47(4):850-856.

13. Zbinden-Foncea H, Rada I, Gomez J, Kokaly M, Stellingwerff T Deldicque L et al. Effects of caffeine on countermovement-jump performance variables in elite male volleyball players. Int J Sport Physiot 2018; 13(2) jb f5-150.

14. Diaz-Lara FJ, Del Coso J, García JM, Portillo LESAreces Fisbian-Vicen J. Caffeine improves muscular performance in etite Brazinan Jiu-jitsu athletes. Eur J Sport Sci 2016; 16(8):1079-1086.

15. Lara B, Ruiz-Vicente D, Areces Abian-Kigen J, Salinero JJ, González-Millán $\mathrm{C}$ et al. Acute consumption gr a caffeinated energy drink enhances aspects of performance in sprint swimmers. Brit J Nutr 2015; 114(6):908-914.

16. Abian P, Del Coso I, Salinero JJ, Gallo-Salazar C, Areces F, Ruiz-Vicente et al. The jingestiongf a caffeinated energy drink improves jump performance and activity patterns in elite badminton players. J Sport Sci 2015; 33(10):1042-1050.

17. Andrade-Souza VA, Bertuzzi R, De Araujo GG, Bishop D, Lima-Silva AD. Effects of isolated or combined carbohydrate and caffeine supplementation between 2 daily training sessions on soccer performance. Appl Physiol Nutr Me 2015; 40(5): 457-463.

18. Abian-Vicen J, Puente C, Salinero JJ, González-Millán C, Areces F, Muñoz G et al. A caffeinated energy drink improves jump performance in adolescent basketball players. Amino Acids 2014; 46(5)1333-1341. 
19. Jacobson BH, Hester GM, Palmer TB, Williams K, Pope Z, Sellers J et al. Effect of energy drink consumption on power and velocity of selected sport performance activities. J Strength Cond Res 2018; 32(6):1613-1618.

20. Ministerio de Sanidad y Consumo. Real Farmacopea Española. Madrid; 2005.

21. Van Hooren B, Zolotarjova J. The Difference between Countermovenent and Squat Jump Performances: A Review of Underlying Mechanisms with Practícal Applications. J Strength Cond Res 2017; 31(7):2011-2020.

22. Tallis J, Yavuz HCM. The effects of low and moderate doses of eaffeine supplementation on upper and lower body maximal voluntary concentrie and eccentric muscle force. Appl Physiol Nutr Me 2018; 43(3):274-281.

23. Gonzalez-Badillo JJ, Marques MC. Relationship between kinematic factors and countermovement jump height in trained track and field athletes. $J$ Strength Cond Res 2010; 24(12):3443-3447.

24. Barker LA, Harry JR, Mercer JA. Relationships between countermovement jump ground reaction forces and jump heightereactive strength index, and jump time. $J$ Strength Cond Res 2018; 32(1):248-254。

25. Kirby TJ, McBride JM, Haines TL, Dayne AM. Relative net vertical impulse determines jurnping performance. J Appl Biomech 2011; 27(3):207-214.

26. Thorlund JB, Michalsik LB, Madsen K, Aagaard P. Acute fatigue-induced changes in muscle mechanical properties and neuromuscular activity in elite handball piayers following a handball match. Scand J Med Sci Spor 2008; 18(4):462-472.

27. García-Pinillos F, Molina-Molina A, Latorre-Román P. Impact of an incremental running test on jumping kinematics in endurance runners: can jumping kinematic explain the post-activation potentiation phenomenon? Sport Biomech 2016; 15(2):103-115.

28. Papaiakovou G, Fotis K, Nikodelis T, Panoutsakopoulos V, Kollias I. Influence of the ankle joint dosiflexion on the execution of vertical jumps. ISBS - 
Conference Proceedings Archive 2007.

29. Del Coso J, Salinero JJ, González-Millán C, Abian-Vicen J, Pérez-González B. Dose response effects of a caffeine-containing energy drink on muscle performance: A repeated measures design. J Int Soc Sport Nutr 2012; 9(1):21-30.

30. Warren GL, Park ND, Maresca RD, McKibans KI, Millard-Stafford ML.Effect of caffeine ingestion on muscular strength and endurance: A metanalysis. Med Sci Sport Exer 2010; 42(7):1375-1387.

31. San Juan AF, López-Samanes Á, Jodra P, Valenzuela PL, Rueda J, Veigå Herreros $\mathrm{P}$ et al. Caffeine supplementation improves anaerobic performance and neuromuscular effciency and fatigue in Olympic-level boxers. Alitrients 2019; 11(9): 2120-2134. 


\section{NOTES}

Conflicts of interest. - The authors certify that there is no conflict of interest with any financial organization regarding the material discussed in the manuscript.

Funding.- Supplementation and translation costs were funded by a competitive research grant from the VIII Announcement of the Banco Santander and Fundación UAX (reference: 1010704).

Authors' contributions. - The study was designed by PJ and RD; data were collected and analyzed by AL-R, PJ, SB, and RD; data-interpretation andinanuscript preparation were undertaken by AL-R, SB, and RB. All authors approved the final version of the paper.

\section{PABLES}

Table 1.-CMJ performance variables recorded for PLAC versus CAFF. Data are expressed as the mean tstandard deviation [95\% confidence interval, CI].

\begin{tabular}{|c|c|c|c|c|c|c|c|c|}
\hline & $\mathrm{AlC}$ & & CAFF & & & & & \\
\hline & $\begin{array}{c}\mathrm{M}+\mathrm{SD}[95 \% \\
\mathrm{CI}]\end{array}$ & $\begin{array}{l}\text { CV } \\
(\%)\end{array}$ & $\begin{array}{c}\mathrm{M}+\mathrm{SD}[95 \% \\
\mathrm{CI}]\end{array}$ & $\begin{array}{l}\text { CV } \\
(\%)\end{array}$ & $\Delta \%$ & $\mathbf{t}$ & $\mathbf{p}$ & d \\
\hline $\begin{array}{l}\text { Height } \\
(\mathrm{cm})\end{array}$ & $\begin{array}{c}32.1 \pm 4.71 \\
{[29.59,34.61]}\end{array}$ & 0.15 & $\begin{array}{c}33.34 \pm 4.44 \\
{[30.98,35.71]}\end{array}$ & 0.13 & 3.86 & $\begin{array}{c}- \\
2.609\end{array}$ & $0.02 *$ & 0.65 \\
\hline T_Ecc (s) & $\begin{array}{c}0.59 \pm 0.13[0.52 \\
0.66]\end{array}$ & 0.22 & $\begin{array}{c}0.58 \pm 0.12[0.52 \\
0.65]\end{array}$ & 0.21 & -1.69 & 0.331 & 0.745 & 0.08 \\
\hline$T_{\text {_Iso }}{ }^{a}(s)$ & $\begin{array}{l}0.022 \pm 0.036 \\
{[0.003,0.041]}\end{array}$ & 1.64 & $\begin{array}{l}0.012 \pm 0.006 \\
{[0.008,0.015]}\end{array}$ & 0.5 & $\begin{array}{c}- \\
45.45\end{array}$ & & 0.082 & 0.29 \\
\hline$T_{\text {_Con }}(\mathrm{s})$ & $\begin{array}{c}0.15 \pm 0.07[0.12 \\
0.19]\end{array}$ & 0.47 & $\begin{array}{c}0.18 \pm 0.07[0.14 \\
0.22]\end{array}$ & 0.39 & 20 & $\begin{array}{c}- \\
0.916\end{array}$ & 0.374 & 0.23 \\
\hline
\end{tabular}


Page 30 of 32

\begin{tabular}{|c|c|c|c|c|c|c|c|c|}
\hline $\begin{array}{c}\text { PP } \\
(\mathrm{N} / \mathrm{kg})\end{array}$ & $\begin{array}{c}51.54 \pm 4.62 \\
{[49.08,54.00]}\end{array}$ & 0.09 & $\begin{array}{c}53.34 \pm 6.00 \\
{[50.14,56.54]}\end{array}$ & 0.11 & 3.49 & $\begin{array}{c}- \\
3.427\end{array}$ & $0.004 * *$ & 0.86 \\
\hline $\begin{array}{c}\text { AP } \\
(\mathrm{N} / \mathrm{kg})\end{array}$ & $\begin{array}{c}28.59 \pm 3.45 \\
{[26.75,30.43]}\end{array}$ & 0.12 & $\begin{array}{c}29.97 \pm 3.67 \\
{[28.01,31.92]}\end{array}$ & 0.12 & 4.83 & $\begin{array}{c}- \\
3.235\end{array}$ & $0.006^{* *}$ & 0.81 \\
\hline $\begin{array}{l}\mathbf{V}_{\max } \\
(\mathbf{m} / \mathbf{s})\end{array}$ & $\begin{array}{c}2.68 \pm 0.16[2.59 \\
2.77]\end{array}$ & 0.06 & $\begin{array}{c}2.72 \pm 0.17[2.63 \\
2.81]\end{array}$ & 0.06 & 1.49 & & $0.023^{*}$ & 0.63 \\
\hline IF (N) & $\begin{array}{c}1.33 \pm 0.3[1.17 \\
1.49]\end{array}$ & 0.23 & $\begin{array}{c}1.44 \pm 0.3[1.28 \\
1.59]\end{array}$ & 0.21 & 8.27 & & 0.06 & 0.51 \\
\hline $\mathbf{F}_{\max }(\mathbf{N})$ & $\begin{array}{c}2.49 \pm 0.25[2.36 \\
2.63]\end{array}$ & 0.1 & $\begin{array}{c}2.59 \pm 0.32[2.41 \\
2.76]\end{array}$ & 0.12 & & & 0.053 & 0.52 \\
\hline
\end{tabular}

Abbreviations: $\mathrm{CV}$ : coefficient of variation; $\Delta \%$ : percentage difference versus PLAC; $t$ : conasest statistic; p: p-value; $\mathrm{d}_{z}$ : Cohen's $d_{z}$ effect size; TT: total duration; T_Ecc. duration eccentric phases $\Gamma_{-I s o}$ d duration isometric phase; $\mathrm{T}_{-}$con: duration concentric phase; PP: peak power; AP: average power; $\mathrm{V}_{\max }$ : maximum velocity; IF: initial force; $F_{\max }$ : maximum force; ${ }^{a}$ : data-distribution for the variable $T_{-}$Iso was non-normal so the Wilcoxon signed rank test was used; *: $\mathrm{p}<0.05 ; * * \mathrm{p}<0.01$.

\section{TITLES OF PIGURES}

Figure 1.- The main results of this study are shown in this figure. Panel A shows jump height (cm). Banel B peak velocisy ( $\mathrm{m} / \mathrm{s}$, Panel C peak power $(\mathrm{N} / \mathrm{kg})$, and panel D average power (Ny/kg). In all panels, bars represent average values for each supplementation condition (PLAC vs. CAFF), and lines show individual results. Abbreviations: $P L A C=$ placebo $; C A F F=$ caffeine $*$ indicates significant differences for PLAC vs CAFF at $p<0.05$ and **at $p<0.01$. 
Page 31 of 32

$\begin{array}{r}1 \\ 2 \\ 3 \\ 4 \\ 5 \\ 6 \\ 7 \\ 8 \\ 9 \\ 10 \\ 11 \\ 12 \\ 13 \\ 14 \\ 15 \\ 16 \\ 17 \\ 18 \\ 19 \\ 20 \\ 21 \\ 22 \\ 23 \\ 24 \\ 25 \\ 26 \\ 27 \\ 28 \\ 29 \\ 30 \\ 31 \\ 32 \\ 33 \\ 34 \\ 35 \\ 36 \\ 37 \\ 38 \\ 39 \\ 40 \\ 41 \\ 42 \\ 43 \\ 44 \\ 45 \\ 46 \\ 47 \\ 48 \\ 59 \\ 53 \\ 55 \\ \hline\end{array}$
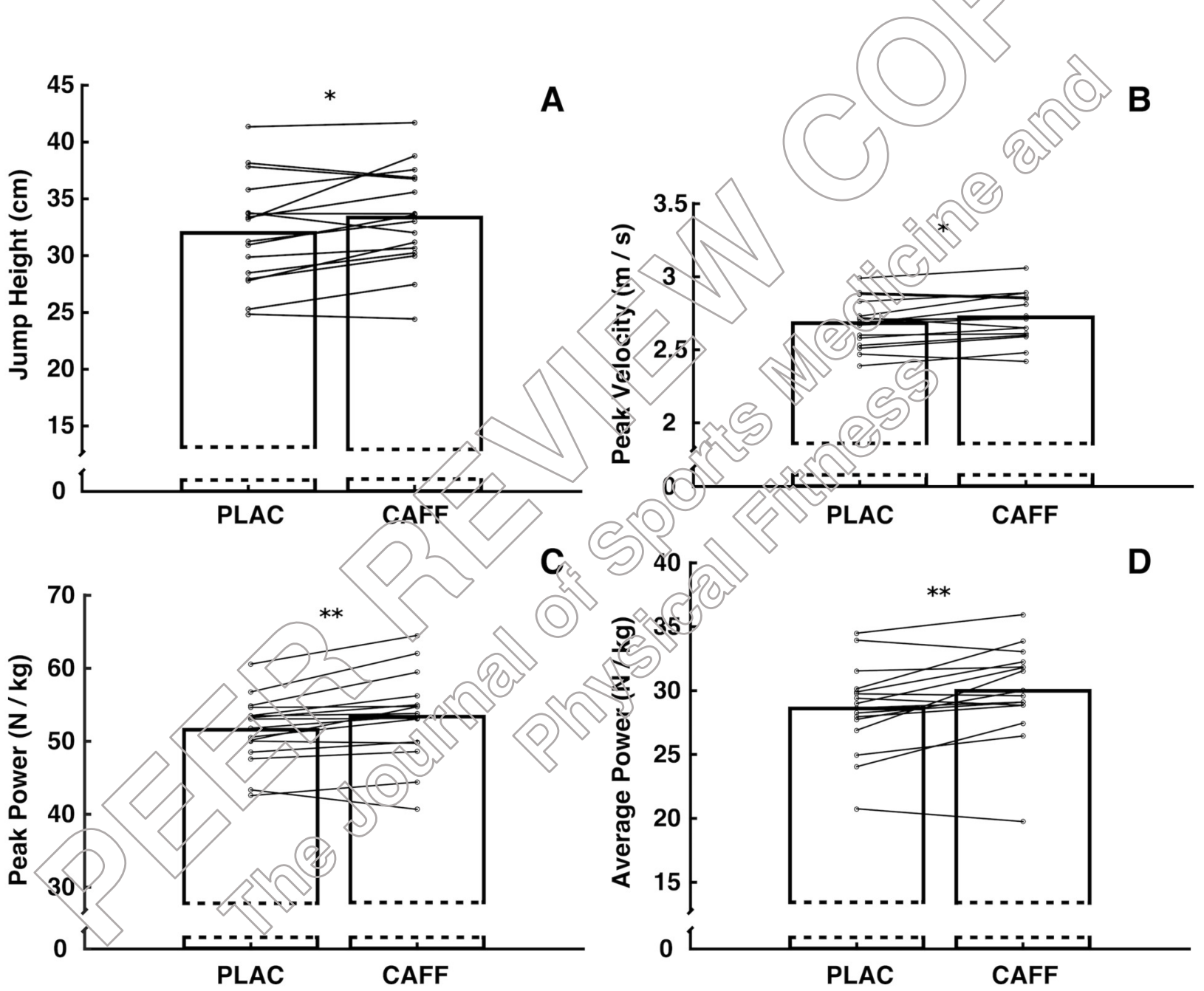


\section{Supplemeptar \$2 Diqjital Material}

1

2

3

4

5

6

7

8

9

10

11

12

13

14

15

16

17

18

19

20

21

22

23

24

25

26

27

28

29

30

31

32

33

34

35

36

37

38

39

40

41

42

43

44

45

46

47

48

49

50

51

52

53

54

55

Download supplementary material file: J Sports Med Phys Fitness-11099 1 V1 2020-04-22.doC

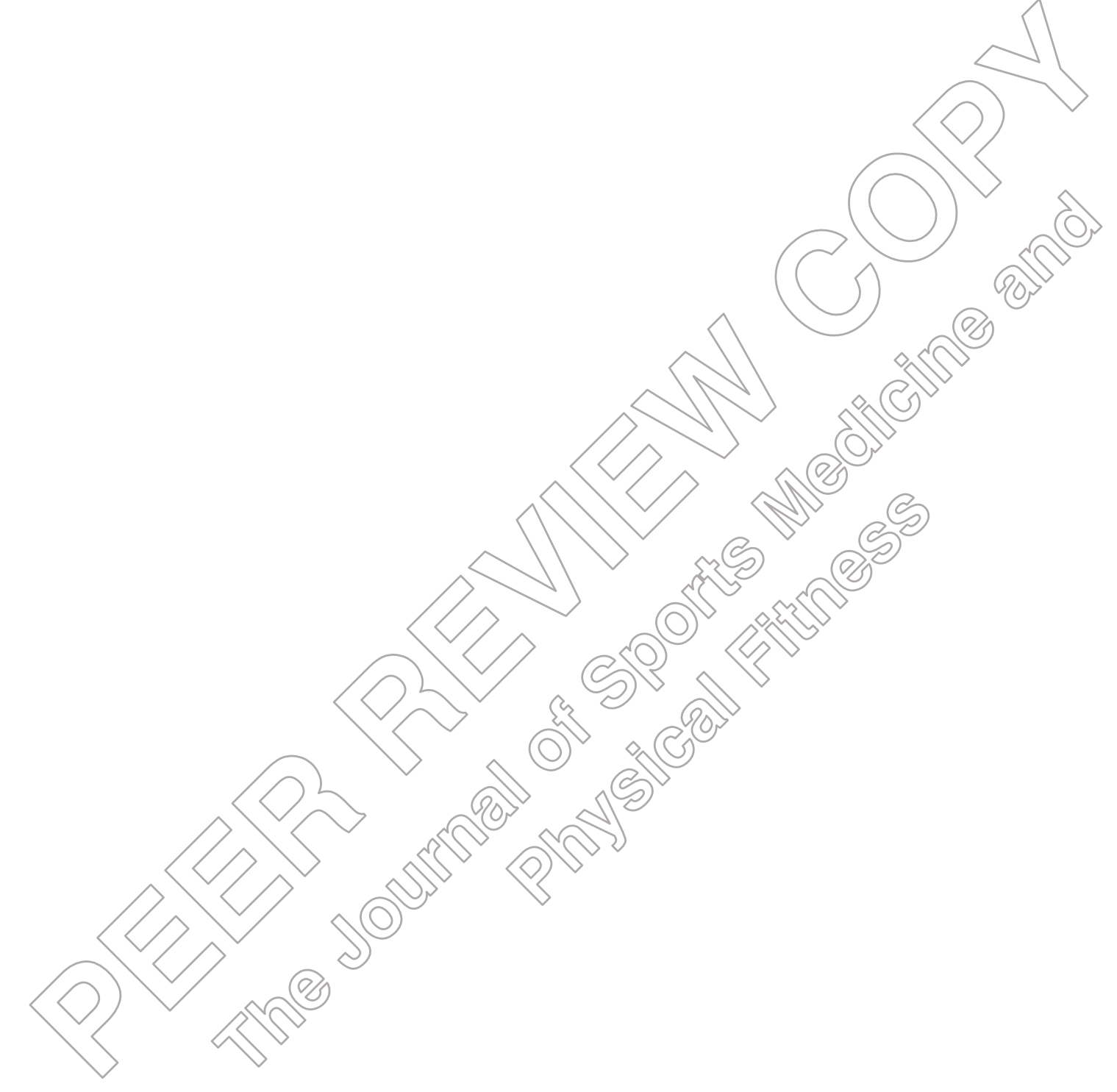

